\title{
The SEA Is Coming: The Future of a Marine Research Facility
}

\author{
Ursula Emery McClure
}

ABSTRACT - This paper originates from a Louisiana State University School of Architecture Research Studio. Charged by the organization's Director, the students investigated the Louisiana Universities Marine Consortium (LUMCON) facility and environment, and re-imagined both the building and landscape as a cutting-edge (albeit remote) research and educational destination. "The SEA Is Coming" Integrative-Design Studio proposes adaptation to climate change as a means to investigate the transformative capacity of a site. Going far beyond the boundaries of current (and future) building program, the studio method provoked profound rethinking of current conventions about coastal change and occupancy, design, community, the environment, and land use. LUMCON's facility sits at the nexus of deltaic land, freshwater, brackish wetland, and salty ocean and provides access to all these systems. It has withstood the volatility of this environment: flooding, hurricanes, oil spills, the Gulf dead zone, salt-water intrusion, etc. Now over thirty-years-old, the building must adapt to changing conditions. The studio investigated LUMCON's ability to continue functioning in its changing environment and further its indispensable research capabilities of the rapidly changing coastal landscape.

Keywords: adaptive reuse, aquatic structures, coastal resilience, climate change, sea level rise

The global ramifications of sea level rise are much greater than merely changing coastlines. The rising seas will not only require populations to retreat but will cause ecosystems to shift, storm proofing to change, 
constructed landscapes to go to ruin and/or require remediation, and coastal building sites to be addressed. It is also important to remember that with the sea comes salt, which will require structures to resist corrosion and that settlements' notions of permanent ground will have to change. Historically and currently, humankind has inhabited the coastal environments of the Earth (39\% as of 2010). ${ }^{1}$ Sea level rise and global climate shifts continue to exert changes upon these environments. These conditions all demand a rethinking of how one builds, environmentally, structurally, systematically, and architecturally.

\section{THE CHANGING COAST AND LUMCON}

All over the world, coastal building sites are being transformed by rising seas. How long can such sites remain viable? As they transform, what is their future when what made them occupiable sites will become something else (from land to water, fresh to salt). In Louisiana, all coastal sites exist in a fragile state: the Mississippi river that fed the coast has been bound, the Gulf of Mexico is rising, and the sub-tropical climate creates more intense storms. Coastal sites are increasingly vulnerable places to build - yet coastal occupation is critical to the state, country, and planet. The Louisiana coast serves as a protective barrier to the largest populations in the state, as the operations base for more than 1/4 of US energy resources, a billiondollar fishing industry, and $40 \%$ of the continents wetland environment. If coastal ecosystems, infrastructures, and society are to continue to thrive, their intertwining must be studied, monitored, and cared for. At the physical and literal forefront of this research lies LUMCON.

"The Louisiana Universities Marine Consortium (LUMCON) was formed in 1979 to increase society's awareness of the environmental, economic and cultural value of Louisiana's coastal and marine environments by conducting research and education programs directly relevant to Louisiana's needs in marine science and coastal resources and serving as a facility for all Louisiana schools with interest in marine research and education." ${ }^{2}$

LUMCON's role as both a coastal research and educational facility is critical as the climate changes within a generation. The values, benefits, and challenges that the ocean offers (especially in ecotone sites) must be constantly investigated for and presented to human populations. If not, as humans generally occupy the land, the ocean and all its relevance to humankinds' survival can be forgotten or seem remote. The facility is designed to sit at the physical edge between land, freshwater, brackish wetland, and salty ocean and to provide access to all the aforementioned conditions. It has withstood the volatility of occupying the ecotone: flooding, hurricanes, oil spills, the dead zone, salt-water intrusion, etc. Now, over thirthy years old, it is time to revisit the facility; not its purpose or even its location, but its ability to transform for both its changing environmental 
context (as the sea is actually coming) and its research capabilities (more imperative than ever). The advancements in technology and science allow the research of these changes to have no bounds but the limits of one's investigative inquiry and access to the necessary materials to research. The LUMCON facility has and desires to continue to provide the physical needs that foster such research in the rich petri dish of Louisiana. To do so, effectively and in the future, requires a facility investigation. How does a building transform from a sub-saturated to super-saturated environment? How does one build to handle the dynamics of water (static and volatile)? How does one occupy, access, research in a building that was once on land but is now surrounded by the sea? How does a building designed for sporadic, short, term, environmental change be reformed to handle long-term changes? How can community (a fundamental component of LUMCON) engage with a facility that gets more and more remote? How can one recycle a building instead of throwing it away? What does it mean to change site but not actually physically relocate?

This paper will present the design research developed by a Louisiana State University (LSU) School of Architecture Integrative-Design Studio. Charged by LUMCON'S executive director and sponsored by the LSU Coastal Sustainability Studio whom advocates projects "to envision and design sustainable systems that reduce vulnerability associated with increased storm strength, land subsidence, habitat degradation, and global environmental change," ${ }^{3}$ graduate students and honors undergraduate students investigated the facility and the environment, and re-imagined both the building and landscape as a cutting-edge (albeit remote) research and educational destination. "The SEA Is Coming" Integrative-Design studio proposes adaptation to climate change as a means to investigate the transformative capacity of a building site. Going far beyond the boundaries of current (and future) building program, the studio method provoked profound rethinking of current conventions about coastal change and occupancy, design, community, the environment, and where buildings can (and should) be (Fig. 1).

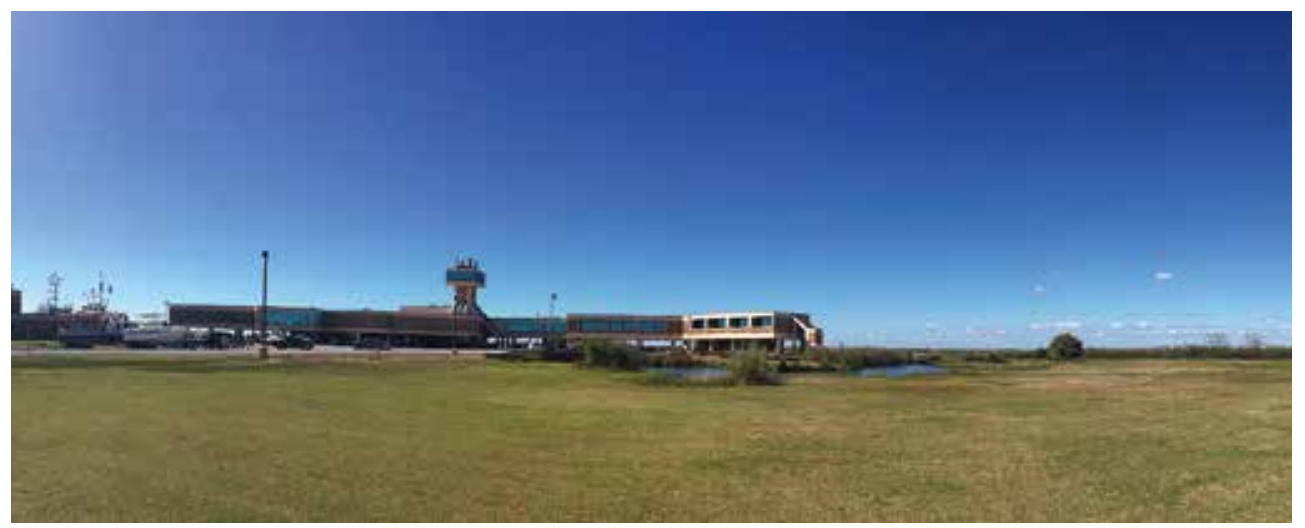

Figure 1. Louisiana Universities Marine Consortium (LUMCON), the W.J. DeFelice Marine Center. 


\section{THE CASE STUDY SITE}

\section{A Building in Water}

Approximately $90 \mathrm{mi}$. [145 km] southwest of New Orleans in Terrebonne Parish, Louisiana (terrebonne means "good earth" in French) lies the smallunincorporated fishing, shrimping, weekender, and crabbing community of Cocodrie. This is where the Louisiana State University Marine Consortium facility is located. Owned by the State of Louisiana, LUMCON currently possesses a 99-year land lease with the Louisiana Department of Natural Resources. ${ }^{4}$ In 1979, "a proposal to form the Louisiana Universities Marine Consortium was endorsed by the Louisiana Board of Regents and enacted into law by the Louisiana legislature in 1979. Architectural planning for the Marine Center began in 1980 and ground was broken for construction in April 1983." ${ }^{5}$ Immediately following this endorsement, five trailers were placed at the site to facilitate research: a library, the administrative offices, the zooplankton lab, the benthos (flora/fauna found on the bottom of a body of water) lab, and the kitchen/dormitory. These trailers were the facility until the completion of the building in $1987 . .^{6}$ The project was awarded through a public bidding process to the design firm O'Rourke, Gossen \& Associates and contracted through The Merlin Group. This was not a typical site for a building and proved to be very challenging. Throughout its construction, it encountered four hurricanes: Danny 1985, Elena 1985, Juan 1985, and Bonnie 1986, which slowed and complicated the construction process. ${ }^{7,8}$

\section{The Ground Condition}

In order to construct the building, the site required modifications. The existing conditions of the ground were not conducive to building such a large structure $\left(75,000 \mathrm{sq}\right.$. ft. [6.968 $\left.\left.\mathrm{m}^{2}\right]\right)$. The community of Cocodrie is located on two overlapping deltaic lobes, the most recent being the Lafourche lobe which formed 2,500 to 500 years ago (a delta lobe is the formation of sediment deposits at the terminus of a river where their current slows and sediment particles drop to the bottom). ${ }^{9}$ The newness of the site's ground is documented in the soil borings taken prior to the building's construction. The borings (Fig. 2) indicated that between the depths of 0 to $50 \mathrm{ft}$. [15 m] the ground consisted mostly of clay, silt, and some organic soils, which are described as very soft to soft. ${ }^{10}$ There were also fragments of wood, which were found but primarily the ground, was clay. The British Soil Classification System"11 classifies soil types "consisting of grains (mineral grains, rock fragments, etc.) with water and air in the voids between grains." The soil types are distinguished according to size, the groups are then further divided into course, medium, and fine subgroups. According to these classifications, clay is classified as the finest soil, followed by silt. Clay soils are flaky and have a high surface value that can carry a small negative electrical charge that attracts water molecules. Possessing this characteristic means clay soils tend to expand and contract 
with the swelling and contracting of water. ${ }^{12}$ This dynamic unstable ground is where LUMCON's occupancy originated and its evolving condition is extremely relevant to the facility's future.

To negotiate the 1980's found ground condition, multiple strategies were employed. First, eight hundred $120 \mathrm{ft}$. long [36,6 m] steel piles were driven to provide a stable foundation for the building. This foundation work was coupled with a cut and fill topographic manipulation in order to complete the necessary harbor for the marine research fleet. The harbor was dredged to a depth of $-15 \mathrm{ft}$. [-4,6 m] mean sea level (MSL) to accommodate the vessels. The dredge spoil stabilized the bulkhead around the harbor wall also was used throughout the site to provide elevated compact fill and level site conditions for the construction of the building. The third strategy towards site development and stabilization was the creation of a $5 \mathrm{ft}$. [1,6 m] high spoil levee around the perimeter of the building site. This site work, completed in stages, created a new, constructed ground for the facility's site.

\section{The Building Condition}

The design for the LUMCON facility (named the W.J. DeFelice Marine Center) required the building be prepared for challenging and dynamic environmental conditions. The most obvious design decision relative to the environmental conditions is that the first floor is $14 \mathrm{ft}$. [4 m] above ground, which at the time of construction placed it about $19 \mathrm{ft}$. [5,8 m] above MSL. This elevation protected it from storm surge and the harsh, salty climate. The second most obvious design decision lies in the buildings

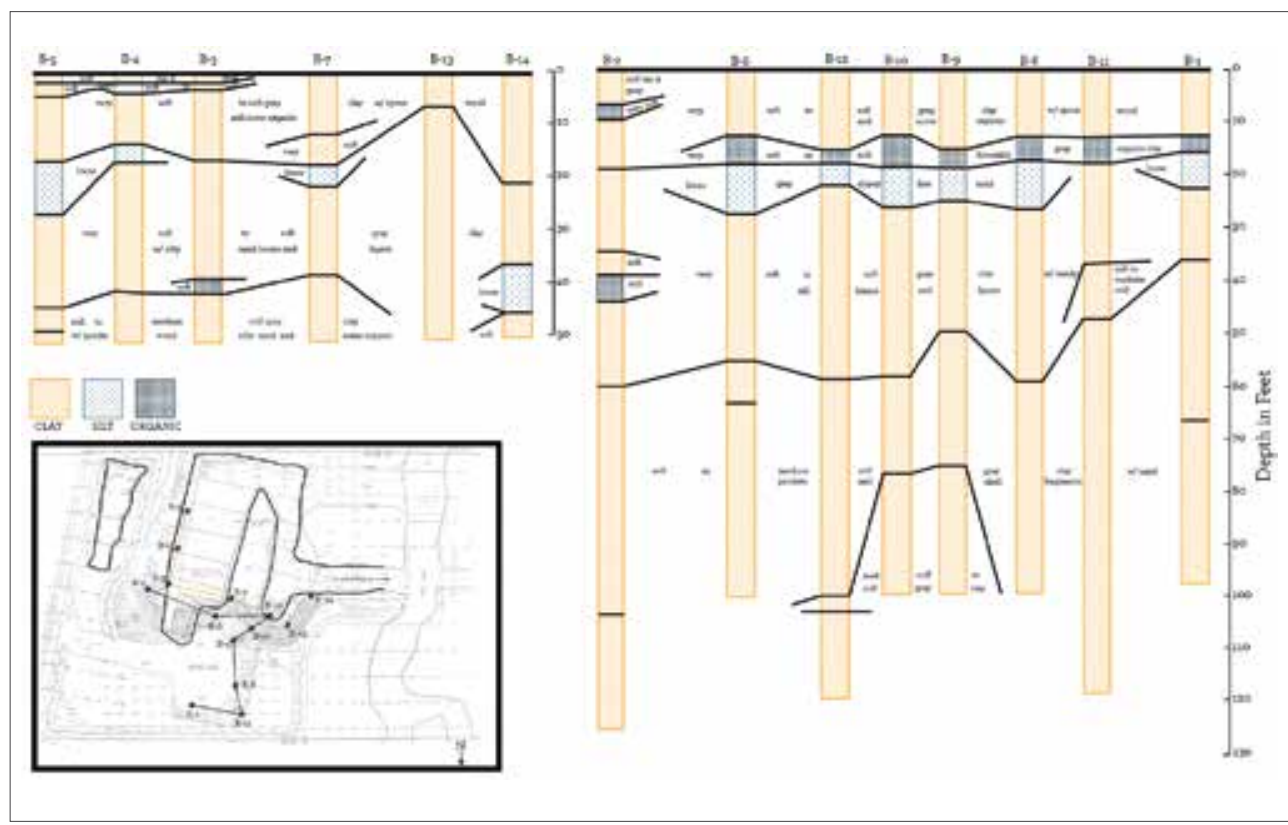

Figure 2. Soil borings diagram and location plan as determined from the 1982 original construction documents. 


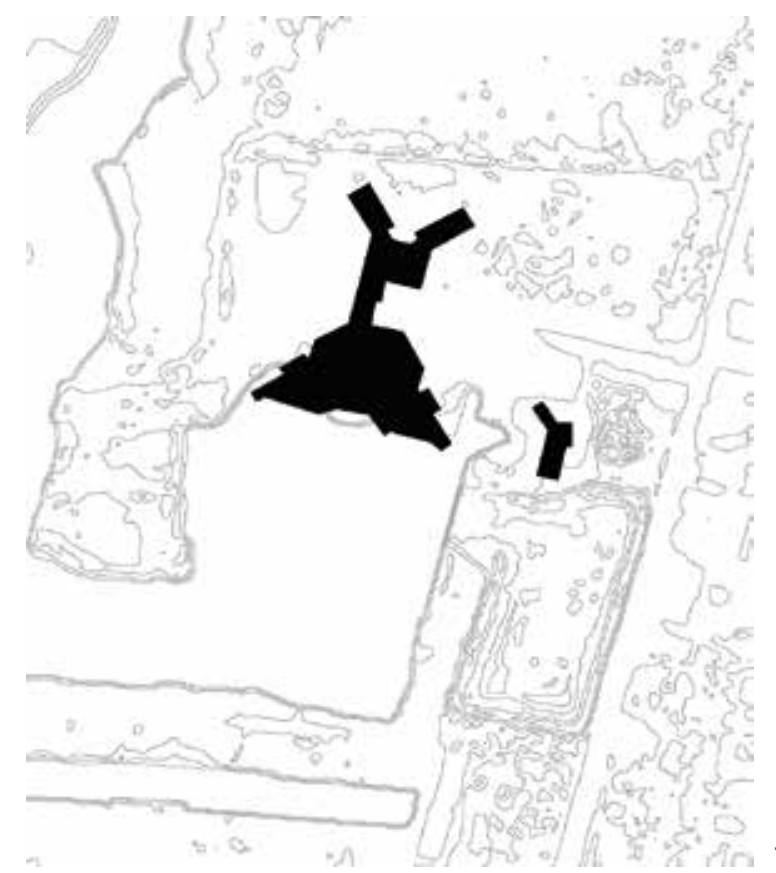

Figure 3. Louisiana Universities Marine Consortium (LUMCON) figure ground.

overall form. Shaped like an eccentric $X$ or a spread eagle, it spreads itself across the site, holding on at multiple points (Fig. 3). No side is very long in any global direction, preventing hurricane force winds from gaining too much momentum on any one side of the building. The third design decision employed was the use of reinforced concrete for both the above ground structure and the cladding. As LUMCON was sited in an estuarine environment, water, and especially brackish water, was a concern. The high corrosiveness of salt to the built environment was well known and thusly, the decision for the superstructure and cladding to be concrete which has resistive qualities to the salt.

The superstructure is composed of poured-in-place columns and waffle slabs (both floor and roof). The columns are many and robust, and create a labyrinth of space under the mass of the building. The $2 \mathrm{ft}$. $[61 \mathrm{~cm}]$ deep waffle-slab (a reinforced-concrete floor and roof construction employing a square grid of deep ribs with coffers in the interstices) ${ }^{13}$ is a two-way waffle slab which distributes the building loads in two directions. This is an important initial design decision for LUMCON because the environment around the building required the floor slab to be able to withstand stronger than normal, unpredictable, external forces. The slabs also must carry the heavy dead load of the concrete structure and precast concrete exterior panels, and the live loads of all the equipment located within the building being utilized by the researchers. These live loads are more excessive than a typical research building as they not only include large mechanical equipment but also large water tanks for marine life. Finally, fastened to these robust slabs, are the ribbed, precast concrete panels. Together, with the superstructure, they compose the fortress of LUMCON. 


\section{The Current Condition}

A gravel road leads off Route 56 and onto the LUMCON site. The building truly sticks out from the surrounding landscape of mostly natural marshlands and elevated fishing camps. The facility now sits outside of post Katrina/Rita/lke/Gustav infrastructure, outside the wall and gates installed to protect the northern side from storms. Here water and land have a complicated relationship. It is difficult to decipher where the land ends and the water begins. This is blatantly apparent as everything built in this environment is built in consideration for the water. Even on the LUMCON site, there are ponds around the building, marsh, and a navigable channel for research vessels.

The site now is comprised of the elevated main building and large fiber-glass containers scattered around the property. These containers hold water and fish that researchers utilize for outside experiments. The maintenance building located southeast of the main building near the harbor, houses much of the mechanical, electrical, and plumbing components for the main building and the maintenance facility for the marine research vessels. Much of this equipment is elevated. Also evident on the site is the presence of a large amount of laboratory equipment and the equipment needed to sustain a functional building. Couple this with a parking lot and harbor full of boats (there are more boats on the site than cars) and it is clear water is omnipresent (Fig. 4).

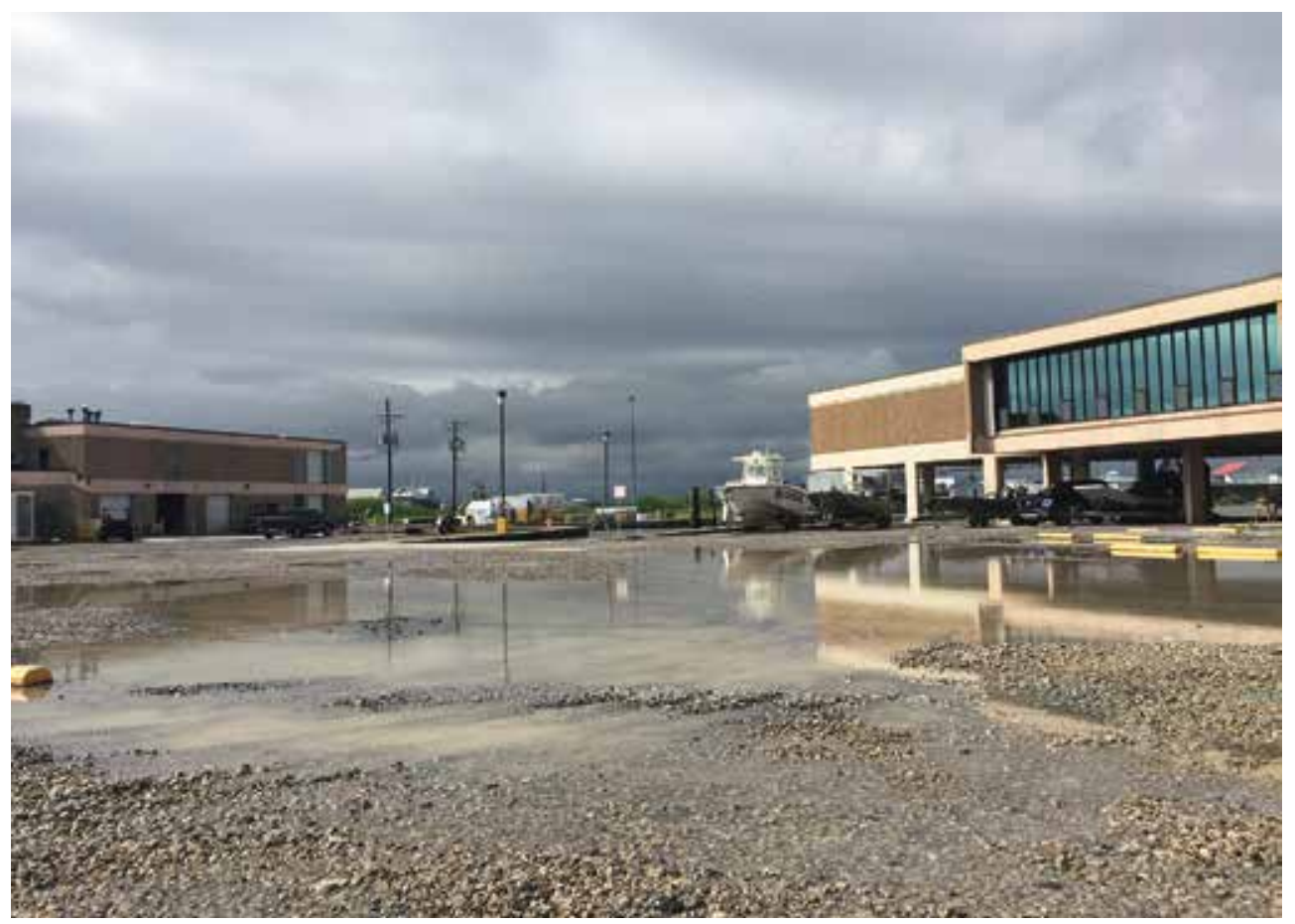

Figure 4. A flooded day at LUMCON. 
The aforementioned design decisions have clearly enabled LUMCON to persist in the environment, as it was determined in 1980. Unfortunately, however, climactic changes have modified said environment. Coastal Louisiana now is affected by subsidence in its deltaic lobes and global sea level rise as well as increased salinity and more intense storm systems. In a student interview with the architect, they asked O'Rourke if the design team had considered subsidence and sea level rise. He responded by acknowledging that there was no consideration taken to address these conditions: "They were not even recognized as concerns." ${ }^{14}$ The firm did acknowledge hurricane strikes, and since the building was completed, the site has weathered multiple storms including Andrew (1992), Ike (2008), Katrina and Rita (2005), although not without effect. Andrew took all the gravel off the flat roof, smashing the windows, and covered the site with sediment. The others have covered the site with up to $8 \mathrm{ft}$. [2,4 m] of water, which of course has marred any materials and equipment not at the $14 \mathrm{ft}$. [4 $\mathrm{m}$ ] level. These events led to window and roof replacement, the addition of balcony to ceiling hurricane shutters, and the complete replacement of all the materials in the entrance lobby. Originally, the materials used were not resistant to flooding (sheetrock and carpet): now they are (brick, concrete, and wood). As for the effects from subsidence, they clearly are present and documented. Shortly after the building was constructed, coastal researchers placed a measuring pole in the site. It shows a 15 in. [38 cm] drop in the ground and this is clearly evident at all ground level slab conditions where the underside of the slab is now exposed in many places and regularly gravel is added to fill the voids and raise the parking areas to re-meet the sidewalks.

As for sea level rise and increased salinity, the students witnessed multiple effects. In the research, they documented the site's current conditions. This included an interview with LUMCON's Marine Superintendent, Joe Marlborough who has worked at LUMCON for 17 years. He is responsible for overseeing the building facilities. As the site faces increasing challenges associated with rising sea levels, Joe constantly tries to stay ahead of the water. It is becoming increasingly difficult. He must now monitor the winds and lunar cycle daily, in order to be ready to mitigate as much damage to the building, their equipment, and the site as possible. A strong high tide can put as much as 6 to $12 \mathrm{in}$. [ 15 to $30 \mathrm{~cm}$ ] of water on the site. If there are southeastern winds associated with the high tide, as much as 18 in. $[45,7 \mathrm{~cm}]$ of water can accumulate on the site as well. If there is 12 to $18 \mathrm{in}$. [30 to $45,7 \mathrm{~cm}$ ] of water on the site, once the water subsides a thick layer of salty silt is left behind on the ground, which needs to be removed from the site. Joe must manage the equipment on site to ensure that none of it will be damaged by water or the left behind silt. ${ }^{15}$ There is also mechanical equipment that runs underground between the maintenance building and the main building. The swelling and contracting of the clayey ground as it absorbs the high tides has created complications for this equipment as well. Finally, the regular inundation of saltier water is rapidly corroding any 
non-stainless metals that become wet. Stair door and elevator sills, exposed rebar, and exterior stair treads throughout the facility are rusting through and now have become part of the replacement maintenance. These repairs and maintenance are an expense of time and money for LUMCON. "Where previously LUMCON was dealing with the acute effects of tropical storms and hurricanes, presently, they have to battle the chronic long-term effects of the rising salt water on a day-to-day basis." 16

\section{THE DESIGN RESEARCH STUDIO}

"The SEA Is Coming" LSU School of Architecture Studio's purpose, as requested by the Executive Director Craig McClain, was to create a design environment that would truly think beyond limits to reimagine the future and adaptive reuse of an existent building fundamentally transformed by climate change. The director also asked, as it is part of his five-year master plan, ${ }^{17}$ to expand the facility to address the growing demand for marine research space at the facility. This design research studio was envisioned (by the author) to challenge the students in a multi-disciplinary environment in the fields of architecture, preservation, landscape architecture, conservation, engineering and other cross-disciplines, and to rethink the adaptive reuse condition at the climate change condition instead of the program typology. The studio asked the students to preserve and interpret the extant facility and environmental fabric and to re-imagine the site as a relevant research and educational destination. Design research encouraged the exploration of issues of access, the relationship between adaptive reuse and design (both architectural, structural, and landscape), off-grid energy consumption, changing climate patterns, water management, land use, and habitat protection. Participants investigated how the transformative ability of a building site can provoke a profound rethinking of our current conventions about coastal change and occupancy, design, community, the environment, and where buildings can be.

Three strategies were employed to begin "The SEA Is Coming" studio, and to engage the students' imagination and give them a platform to approach the design challenge. The first strategy was the provision of questions (see the section The Changing Coast and LUMCON above) and occupational requisites for them to address in their design resolutions, which read as follows:

Requisites for a Future Continuum

1. The major components of the program can and should be combined uniquely.

2. A position regarding "building in water" must be determined.

3. The multiple occupancies/programs that occur on the site will demand thresholds/transition points: between types, between scales, between actions, between amounts of action.

This is a design opportunity. 
4. The relation between land and sea and sea and land is a critical juncture. It is at the foundation of this project.

5. Tectonics that provide resistance to salt must be applied. The building's structure must be modified to resist the corrosion of changing salt levels.

6. All facilities must be off the grid. This includes the lodging and any spaces for the research.

7. All additions to the site must be able to handle storm systems and surge.

8. All lodging spaces must have direct access to the exterior.

9. Lodging/Research can be a component of any other part of the program.

10. All facilities must do no harm to the nature of the site and its surroundings.

11. All facilities must adapt to the Americans with Disabilities Act Accessibility Guidelines (ADAAG).

12. The Public Dock should be close to the facility's dock areas but not interfere with facility operations.

13. The entire site must be designated. This includes but is not limited to under building areas, nature experiences, designated planting areas, etc.

14. How will land dwellers and students engage the site in conjunction with researchers? A visit to LUMCON will change if the ocean surrounds the facility. How the facility receives visitors, educates, and engages them in their environment must be questioned. Now visitors arrive by car, walk around, and leave land to get into boats. How does those activities happen in the future?

\section{Terrebonne Bay Site Variables}

1. Erosion, sea level, salt escalation, storm, and flooding must be designed for as an existing and continuous condition.

2. The site is in a Federal Emergency Management Agency (FEMA) Flood Zone and the Base Flood Elevation (BFE) will need to be addressed. This is not to say elements of the project cannot fall below but if so, must do so responsibly.

3. The act of construction is destructive. This is not an option at this site. What is constructed must make up for its destruction and actively rectify any destruction it causes daily. This site is to be one of positive healthy growth for all components (visitor access, healthy estuary, protected research etc.).

4. The site is flat and exposed. It exists in rawness. The weather and the water take advantage of this rawness and wreak havoc. A position on how to negotiate exposure must be taken.

5. What is land in the open sea? Can this project be the land? How can one provide an advantage of land with an architectural research facility and do so without interruption to the condition? It will change the site but how will it participate in the change? 
The students had to address these questions and statements, distributed on the first day of the studio, in their final design resolutions and their research documentation. Each student had to have a response to each point and by mandating their response, they could formulate clear concise positions to the greater overarching challenge of building in water (Fig. 5).

\section{World Building}

The second strategy employed "world building" and amphibious constructions. To initiate this strategy, students watched ten environmentally specific science fiction films and were instructed to focus on the films' contextual environs. The films included The Lorax (1972), Dune (2000 Sci Fi series), Alphaville (1965), The Matrix (1999), Silent Running (1972), Mad Max 2 (1981), Waterworld (1995), The Road (2009), Star Trek: First Contact (1996) and Blade Runner (1982). Then, to begin the process of designing in water, they had to investigate amphibious constructions, plants, machines, animals, etc. The goal of this investigation was to gain a composite understanding of the workings that allow the amphibious to move between land and water successfully and to look at different precedents that acted as the future facility demands. Amphibians were also selected because of their relationship to environmental change.

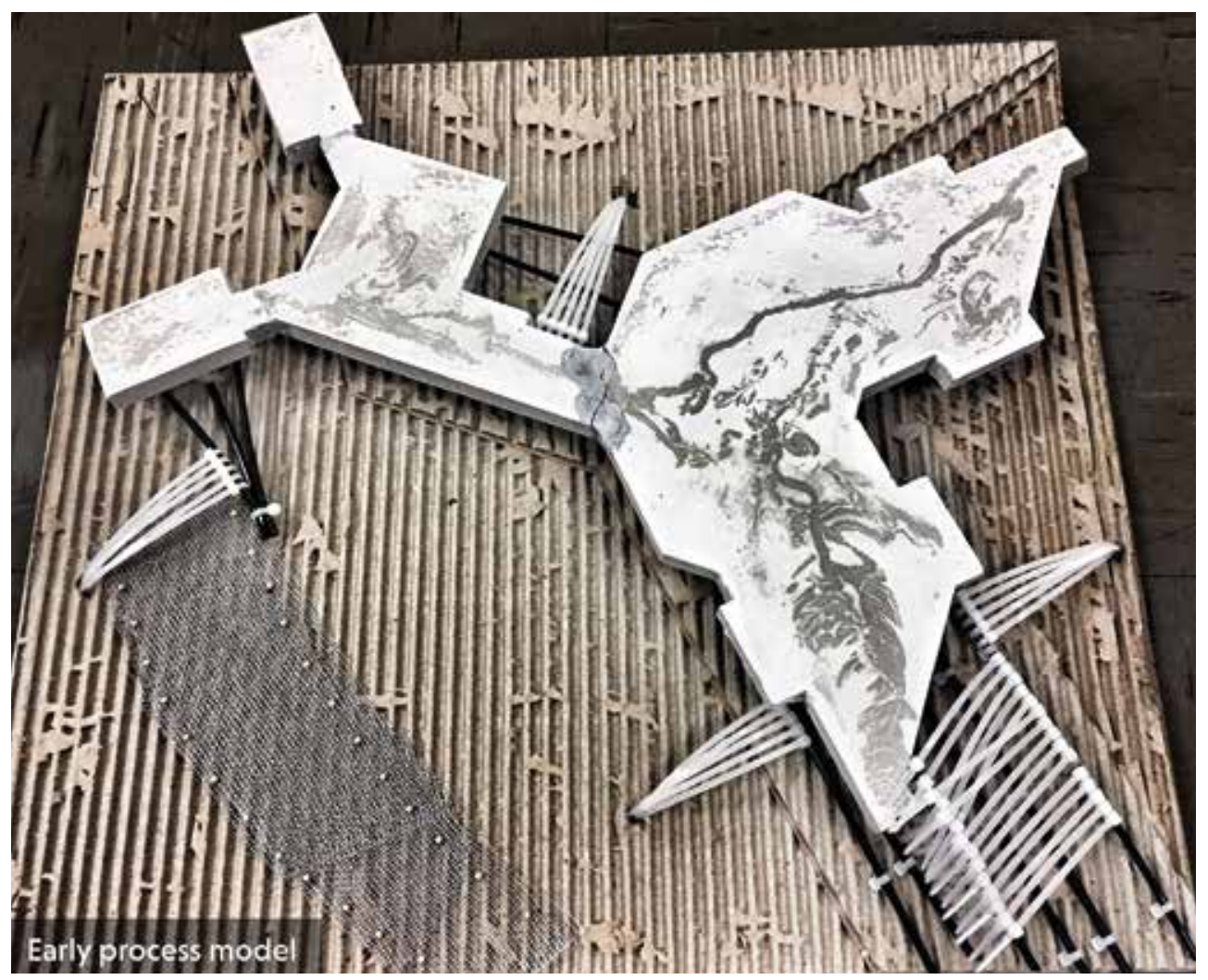

Figure 5. Analytical study model. 


\begin{abstract}
"Amphibians are considered ecological indicators, as they are sensitive to pollutions and environmental changes. The global population of amphibians has seen a dramatic decline with many species becoming critically endangered or even extinct. A lot of local populations have also vanished and the situation is similar all over the world. Scientists are not sure as to the reason for this dramatic decline, but according to the main hypothesis water pollution is the worse culprit. Other reasons for the dramatic decline in amphibian populations around the world are habitat loss, climate change, invasive species, over exploitation, disease and the destruction of the ozone layer." 18
\end{abstract}

The assignment brief instructed them to troll the world of the amphibious and analyze their selections for the salient characteristics that enable it to act amphibiously. What is it made of, how does it stand up, what are the parts, what is the whole, what is the assembly? How does it hold on to land, to water? What is its temporal occupancy, and is it seasonal? How does it negotiate the environment? What does it mean, what does it do? Does it transform, and can one document that? Does it operate differently depending on its location? What are its defenses? What are its weaknesses?

Once this research analysis was completed, each student had to compose the salient characteristics into a new Amphibious Construction. They had to use two and three-dimensional collage methods, and the constructions created had to be occupiable and illustrate systems of assembly (parts, components, joints, etc.) and materiality (Fig. 6). They also had to illustrate

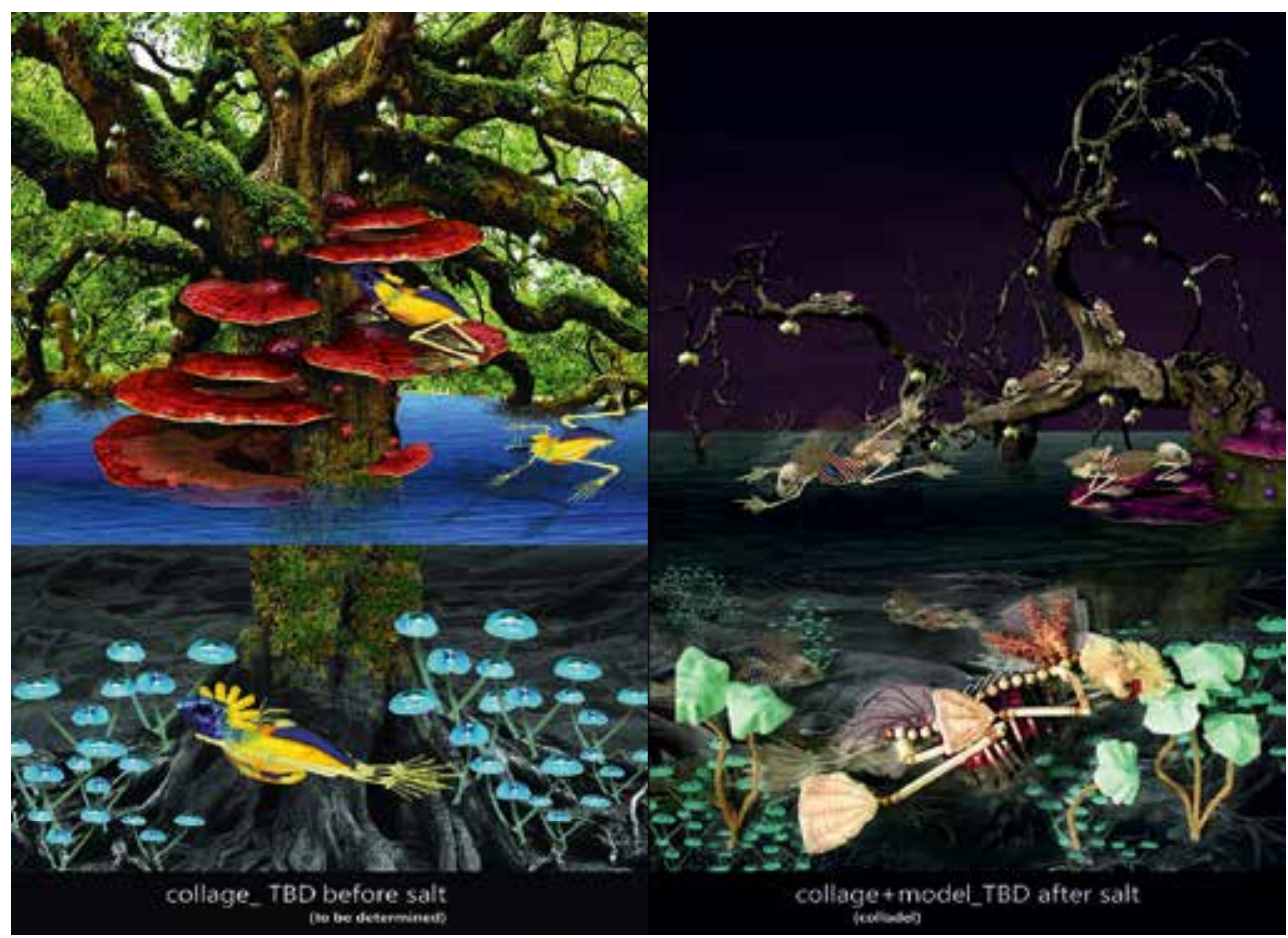

Figure 6. Amphibian constructions and the built worlds they occupy. 
an occupancy of both land and water. To achieve this the author instructed the students in the design act of "world building." World building is the process of constructing an imaginary world, sometimes associated with a completely fictional universe. ${ }^{19}$ The term "world building" appeared as early as 1965 in science fiction criticism, and is used in relation to sciencefiction or fantasy stories and games. ${ }^{20}$ The resulting world may be called a constructed world. Developing an imaginary setting with coherent qualities such as a history, geography, and ecology is a key task for many science fiction or fantasy writers. World building often involves the creation of maps, a backstory, and people for the world. Constructed worlds can enrich the backstory and history of fictional works, and it is common for authors to revise their constructed worlds while completing its associated work. ${ }^{21}$

This was a critical learning objective for "The SEA Is Coming." To develop the LUMCON facility for its future and address its dynamic environment, a future must be determined. Current climate change however, does not allow for that determination. It is too unpredictable, too rapid, and the data is conflicting. Thusly, to respond to the design questions asked of them, the students would have to propose a future environment. They would have to construct an environment (build the world) where the future LUMCOM would reside (Fig. 7). This objective, illustrated by the science fiction films, the students practiced with the amphibious investigations. Each amphibious construction occupied an environment and that environment determined and/or was determined by the amphibious construction. The students had to create both simultaneously. The overall goal of this assignment, which

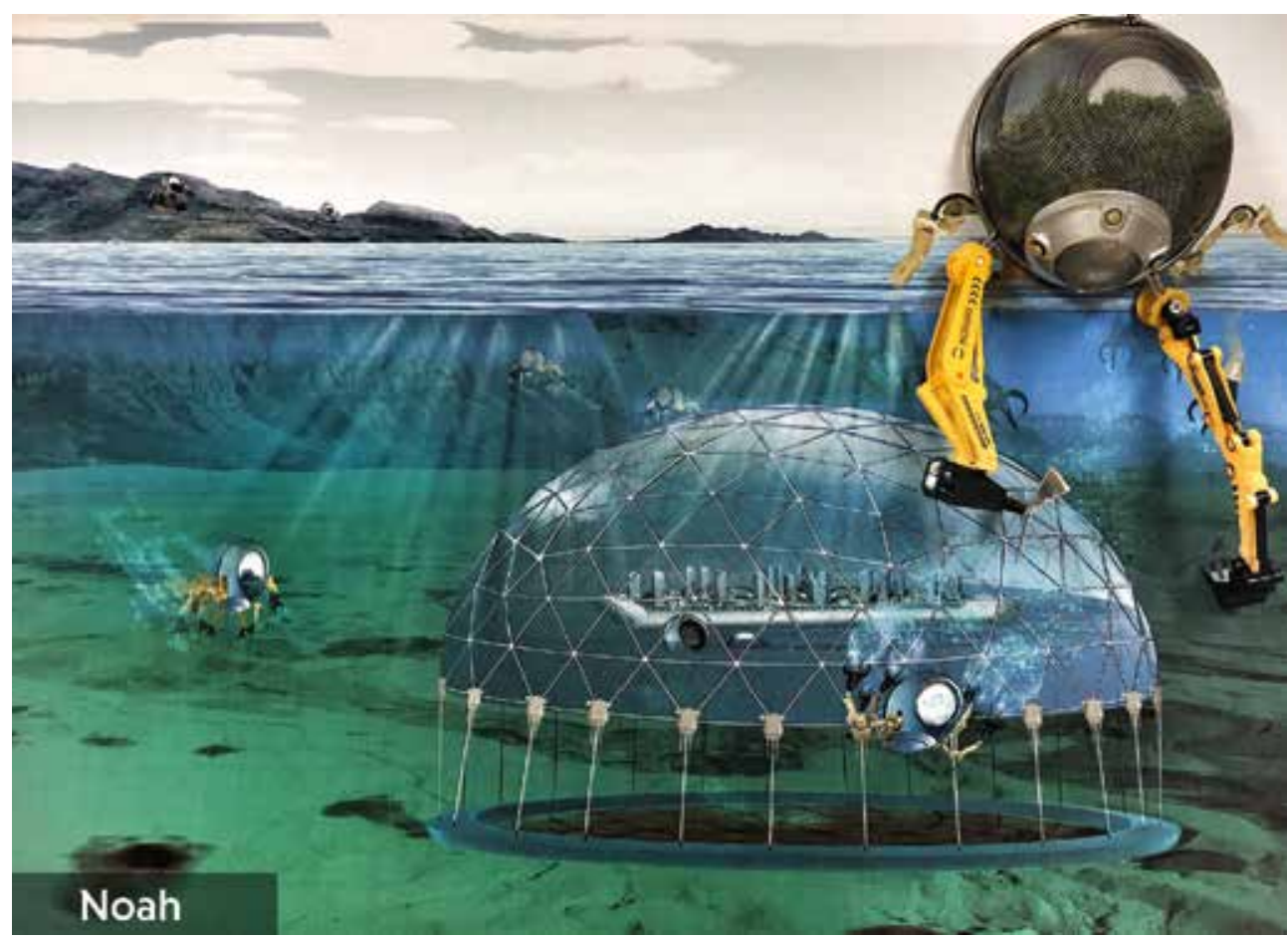

Figure 7. Amphibian construction and the built world it occupies. 
had multiple reiterations, was to remove the students from the typical building typological analysis, which was in no way applicable, and to teach them how to imagine and to occupy unpredictable futures.

\section{Field Immersion}

The third strategy employed to enable the students was site immersion. In the first part of the semester, the studio engaged in a continuous seven-day field excursion into all of Louisiana's coastal ecosystems: the purpose to immerse fully into LUMCON's immediate site and expanded research field. They began with an extended stay at the facility where they occupied the facility the same way the marine researchers do, toured the facility, interviewed various users and the director, and conducted a visual site catalogue. From LUMCON, which lies in the center of the state's coast, the studio then travelled from the western border to the eastern border and then back to the center (ending at Grand Isle.) The field excursion, guided by the closest parallel east-west coastal road, took every access, dirt, gravel, mud, or asphalt, to the coast (Fig. 8). The route travelled passes through three distinct landscapes: the East Gulf Coastal Plain (the Florida parishes) the Mississippi Alluvial Plain (deltaic plain), and the West Gulf Coastal Plain (Chenier plain). The roads traversed and the environments experienced stayed in the 0 to $5 \mathrm{ft}$. [1,5 m] above sea level topography which characterizes $90 \%$ of the natural lands below Interstate 10. Even though the topography is relative between the plains, the environmental conditions vary greatly and is discernable through physical engagement. The relationships between land and water consistently change at each

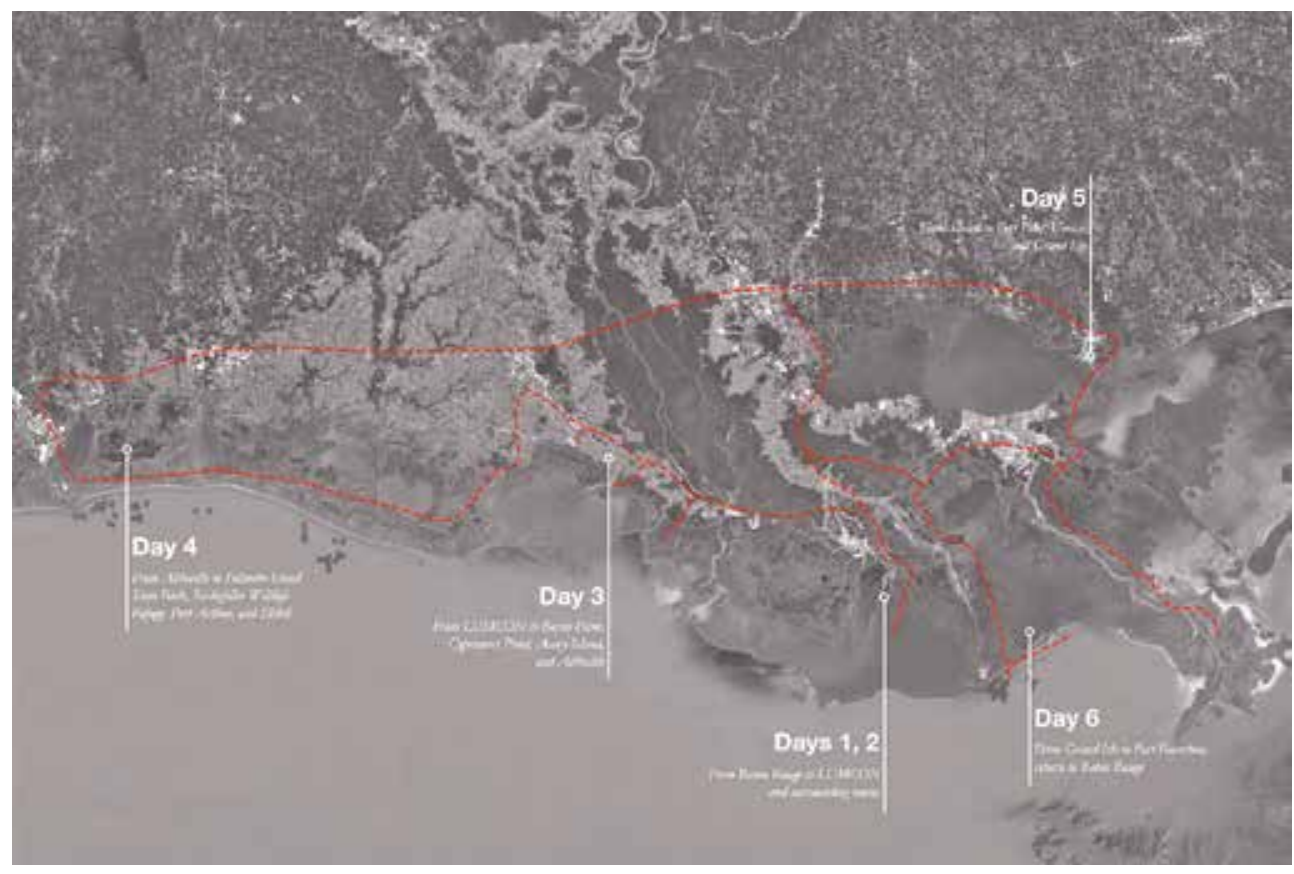

Figure 8. Field excursion map as followed by the studio in January 2017. 
stop, sometimes subtly, sometimes dramatically, and the linear and continuous excursion makes these changes more apparent and relevant to the observer. At each stop, the students engaged and then documented the ecosystem, physically experiencing both land and water conditions. Sometimes that was with their bare feet, sometimes with their tongue (tasting water for varying salinity levels), and always with their eyes, ears, and noses.

\section{Example Stop 1: The Mississippi Alluvial Plain, Cypremort Point.}

At Cypremort Point, the students find an active sediment deposit from the Mississippi River outflow. The constructed park beach lies directly in the deposit field of the westerly currents and thusly, when the studio arrives to document, they find no beach. Instead, they find a shore of black $2 \mathrm{ft}$. [61 cm] deep silt. They walk and sink into the silt until their toes hit sand. This is the land? As they stand on human made ground knee deep in silt deposited by water, the studio discusses the impermanence of the experience.

Primary observation: ground is not guaranteed and if it is constructed, nature will modify it. (Fig. 9)

\section{Example Stop 2: The West Gulf Coastal Plain, Holly Beach}

At Holly Beach, the students experience a gulf shore community constructed immediately on the narrow strip of plain that has been covered with sand. To the south is the wide expanse of the Gulf of Mexico, to the north,

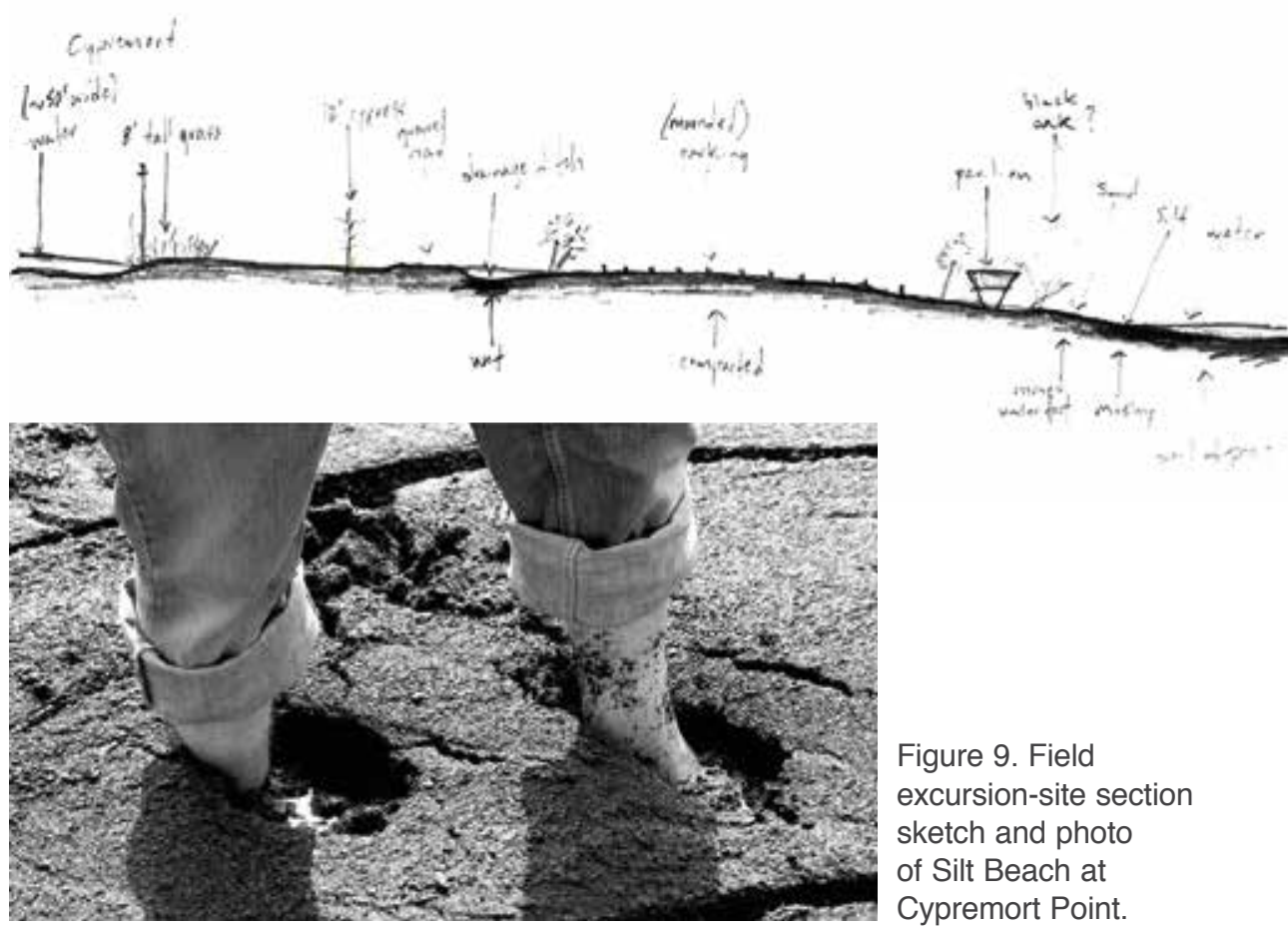


four parallel roads lined with houses on stilts $20 \mathrm{ft}$. [6 m] in the air followed by subsiding wetlands. It is so flat that there is salt water from the sea puddling on the roads and seeping into the wetlands. Some $50 \mathrm{ft}$. [15 m] from the Gulf shoreline, marching like soldiers east to west, lie constructed breakwaters, identical in form, shape, and position. There are no wetlands to protect this exposed condition.

Primary observation: flatness and the sea is treacherous for humans and requires elevation (Fig. 10).

\section{Example Stop 3: The East Gulf Coastal Plain, Fort Pike}

At Fort Pike, the students tour a historic building that now sits in an estuarine lake. It used to sit on compacted fill in a marsh, $100 \mathrm{ft}$. [30,5 m] from a small access channel that passed between Lake Borgne and Lake Pontchartrain. Repeated storm action over the last 150 years, rises in salinity, and subsidence have resulted in a building in the water, accessed by a bridge, and precariously protected by a rock jetty. Throughout the structure, the effects of existing in such a condition are present.
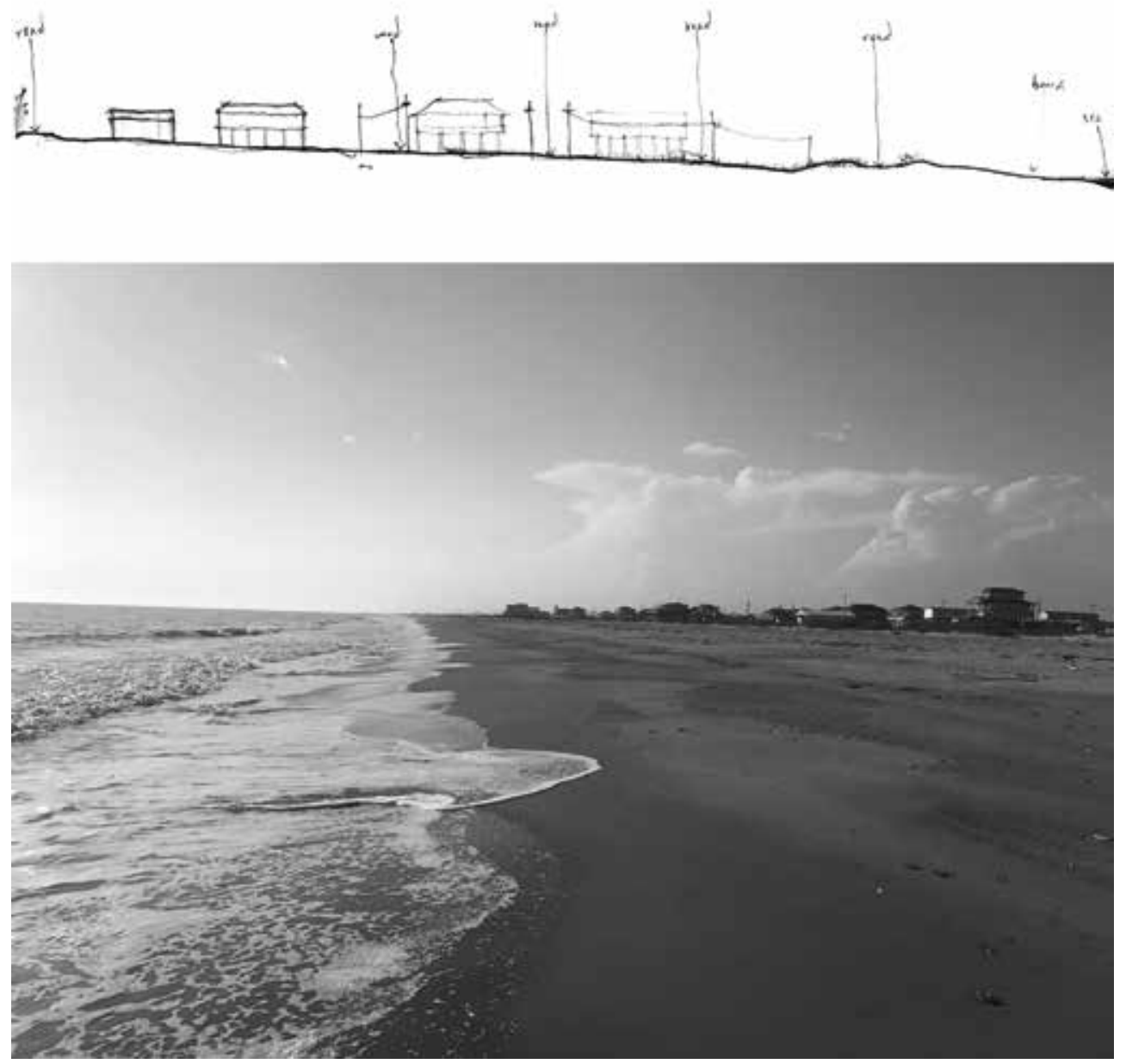

Figure 10. Field excursion-site section sketch and photo of Holly Beach. 


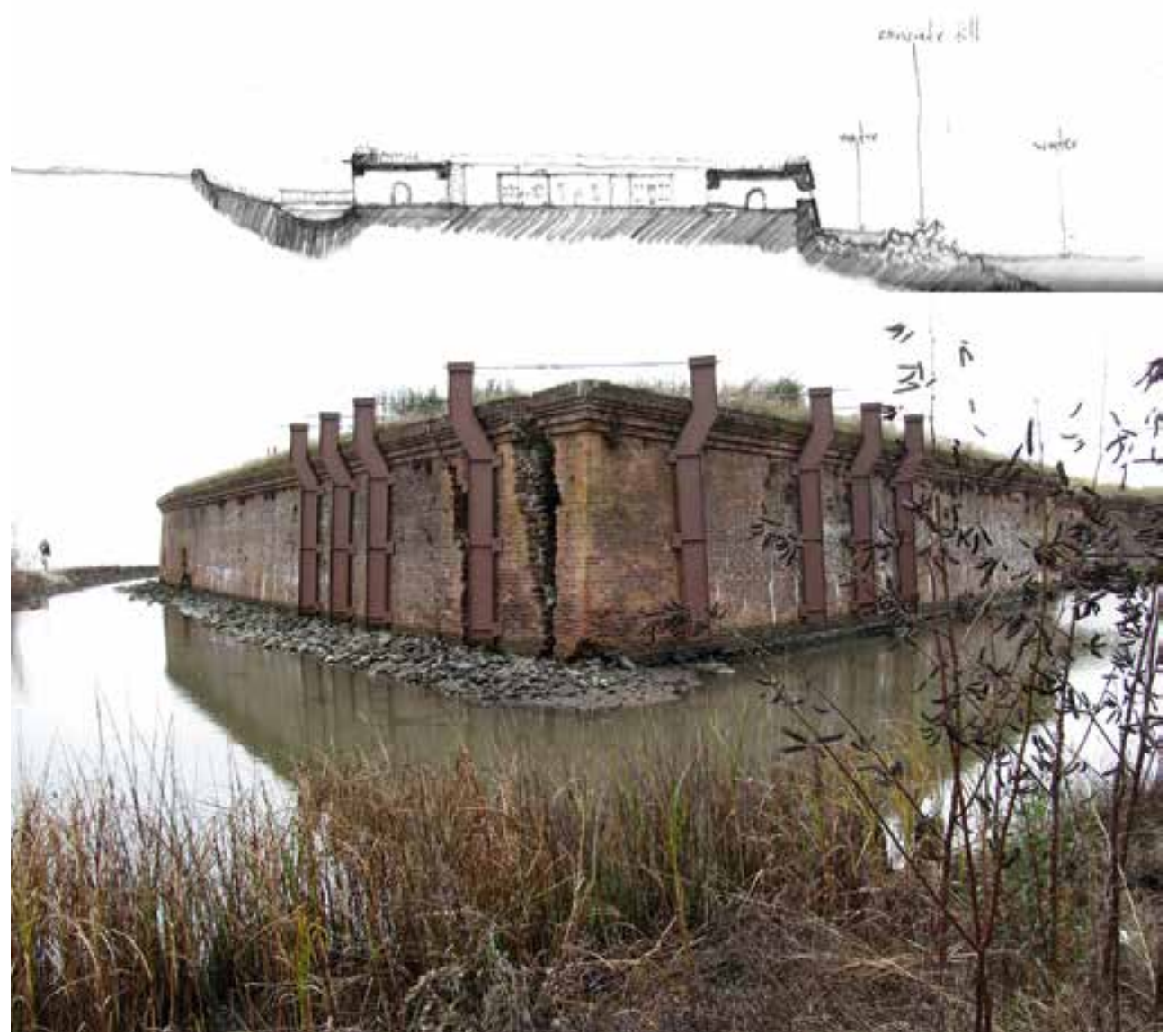

Figure 11. Field excursion site section sketch and photo of Fort Pike.

The $7 \mathrm{ft}$. [2 m] thick walls are now pinioned together with steel braces, the floors are slippery with mud from daily tide action, and salt crystals drip from the vaulted ceilings.

Primary observation: the sea has arrived and maybe buildings can engage. The students have optimism. (Fig. 11)

The field excursion also included many waterborne experiences, both motorized and manual, that took the students out deep into the Gulf of Mexico and into the inner waterways. All these sensorial engagements were documented on-site with camera, recorder, and field guides and then transcribed later in their research books. These strategies and events occurred in the first month of the project. The initialness was both strategic and necessary. Getting the students fully entrenched in the coastal edge condition was needed for their comprehension of LUMCON's environment: both the immediate (where the building lies) and the remote (which defines the marine research field). It was strategic in that from the onset of the design investigations, the students were analyzing the design challenge through a land and water environmental lens and using said lens to imagine and construct a future. If these strategies had not initiated "The SEA Is Coming" studio, the director of LUMCOM's challenge to imagine the future 
for the facility, would not have occurred. The students would have merely tried to solve the problems that exist now and with what they could quantify instead of utilizing adaptation to climate change as a means to investigate the transformative capacity of a building site.

\section{CONCLUSIONS}

Following the initial investigations, analyses, and research, the studio moved forward with the actualization of the initial work into design constructions. This included not only the future of the building facility but also the future of the site and how LUMCON would operate as it moved toward and into the future. Since this was an integrative design studio, defined by the National Architecture Accrediting Board as the "ability to make design decisions within a complex architectural project while demonstrating broad integration and consideration of environmental stewardship, technical documentation, accessibility, site conditions, life safety, environmental systems, structural systems, and building envelope systems and assemblies," 22 the students' final projects had to present a developed architectural response. This pedagogical combination of the imaginings this challenge necessitated and the realities a complex architectural project demands led to innovative solutions and suggestions for LUMCON.

The course concluded with the students presenting their design research to a critical panel including the Executive Director. Each student also prepared a self-authored book of his or her research development. These comprehensive books were written throughout the entire semester as their designs developed and they record all the data, investigations, analyses, etc. that support their design decisions. They all conclude with their final project determinations. These books are now part of the LUMCON library and the Director and his team plan to utilize the student's work, especially the graphic investigations, as they move forward with LUMCON's development.

This is not a polite gesture. Since the studio completed in May of 2017, the author has had to present the findings of the research studio to Grapple. Grapple $^{23}$ is LUMCON's Growth \& Planning Panel and is composed of coastal scientists, planners, engineers, state politicians, designers, levee administrators, building maintenance, and emergency responders. Just as it was for the students, it is difficult for the panel to look far into the future and thusly the inclusion of "The SEA Is Coming" studio research. The studio acts as the bridge between the highly conceptual and the practical and serves as a think-tank for the facility's planning future. At Grapple's May 23 opening meeting, the agenda began with three presentations, a politician, a sea level scientist, and a designer (the Author). As stated on the agenda, "the presentations are to facilitate discussion [...] to help us understand what we need to think about as we plan for sea level rise, how changes 


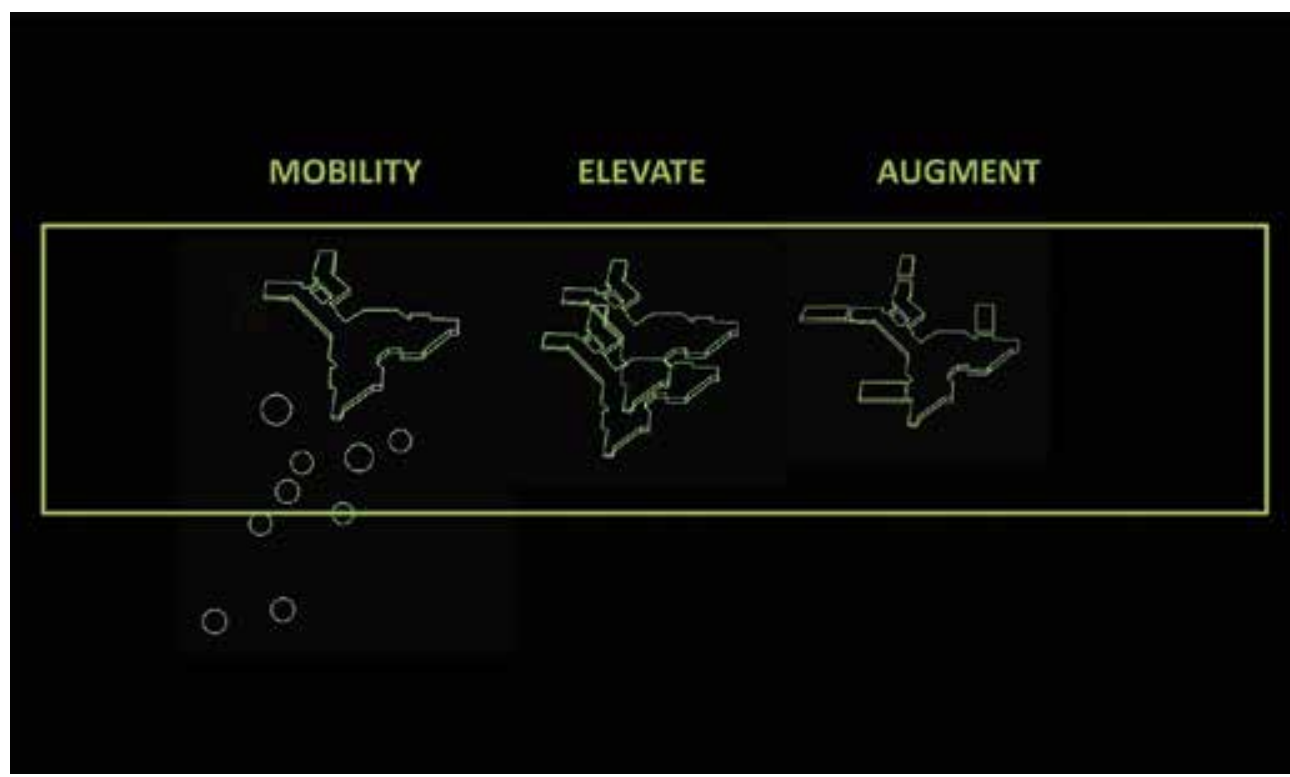

Figure 12. Diagram of Future Themes for development presented at the GRAPPLE meeting.

in the operation of LUMCON's Marine Center may impact you, and how we can utilize the changing landscape as an opportunity to expand our operations." ${ }^{24}$ For the panel, one of the first responses to this discussion was flight; for LUMCON to abandon its current location and facility and move inland, behind the flood wall as far away as Houma (31 mi. [50 km] north), the closest city. This is the practical, unimaginative, and non-adaptive response. The studio findings presented three alternate responses. In summation, LUMCON could develop in the following ways (Fig.12):

\section{Augment.}

Because of the spread-eagle siting of the facility, a portion of the students developed future schemes that augmented and extended the wings. This required the existing column structure to be treated for a saturated saline environment and that all the extensions modify how the facility engages the entrance surface (be it water or ground). The augmentations reworked the entire relationship between inside the raised facility and outside on an indeterminate surface, and provided flexible augmentations that could adapt to changing conditions. Most of these schemes also modified the site to allow water to be present to release some of the pressure and effort it currently takes to hold it back (Fig. 13).

2. Elevate.

Because of the structural system and the resistance the elevated facility has already presented, a portion of the students added vertically to LUMCON and proposed new programming strategies that allowed for LUMCON to continue operations as it and the sea rises. These schemes saw the vertical development 

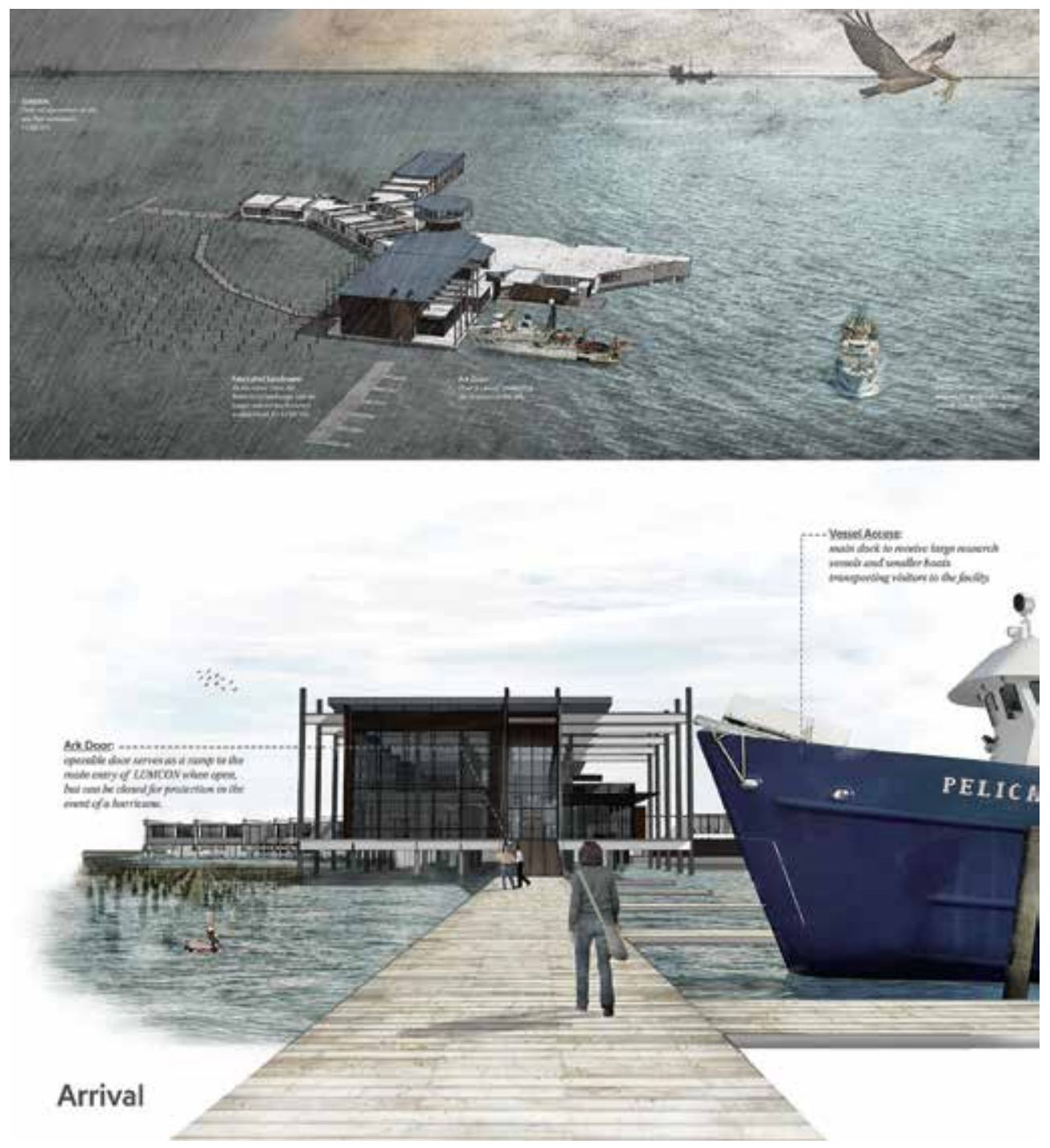

Figure 13. Augment: final images of design proposal by LSU BArch student, Jacob Thevenot illustrating wing extensions that negotiate the changing surface levels and provide new access for land or sea entry.

as a staged procedure, a slow creep, and imagined the ways current operations would also creep up, opening the ground and the original level of the facility to the changes in the surrounding environment. Most of these students built worlds where the sea surrounded the facility but the facility maintained its position (Fig. 14).

3. Mobility.

The third response that most of the students developed was one of mobility. This was not a mobility that abandoned the facility, but one that enabled the existing facility to stay in operation as long as possible. This response, as all the others, began with treating the existing the facility for more salinity. Modular construction, boat building, and oil-and-gas industry 

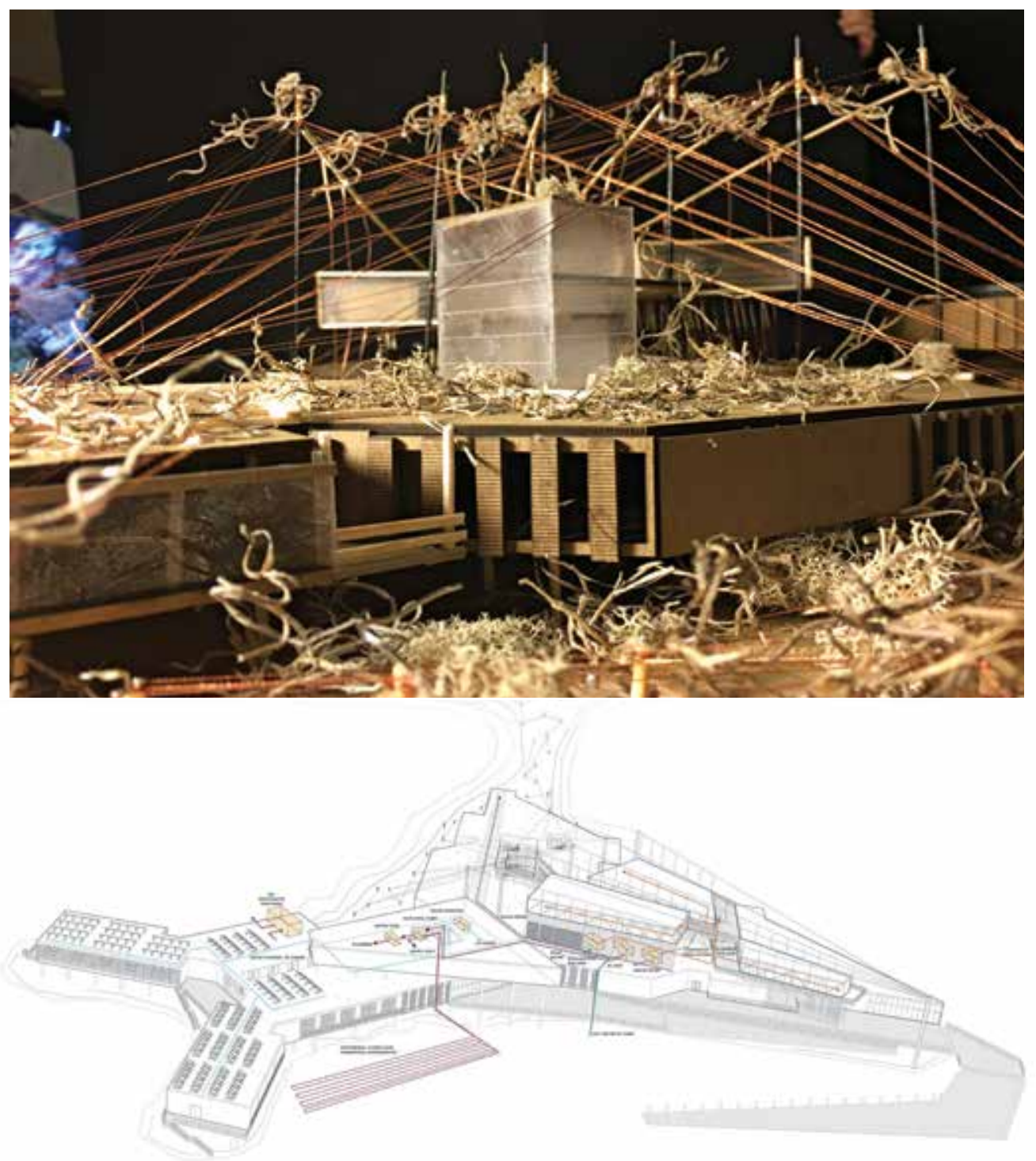

Figure 14. Elevate: systems axonometric and final model of LSU MArch student Kim Breaux. Her resolution proposed a slow retreat vertically, where the future occupancies used the existing facility as its new ground, and her additions not only created occupancy for the facility but also for the environment with constructed wetlands.

sea operations heavily influenced these projects. The existing facility in all these schemes became the docking station for a myriad of new vessels that could plug into LUMCON. Depending on the project, these vessels presented a spectrum of options Some were high performance laboratories similar to the research vessels the students had visited, some focused on lodging allowing the existing facility to utilize that space for research, some took over all of the system infrastructure (water, energy, was, etc.), and a few of them acted as a mobile LUMCON. An entire system that could float or be hauled away and remain operational after the existing facility is determined obsolete (Fig. 15). 

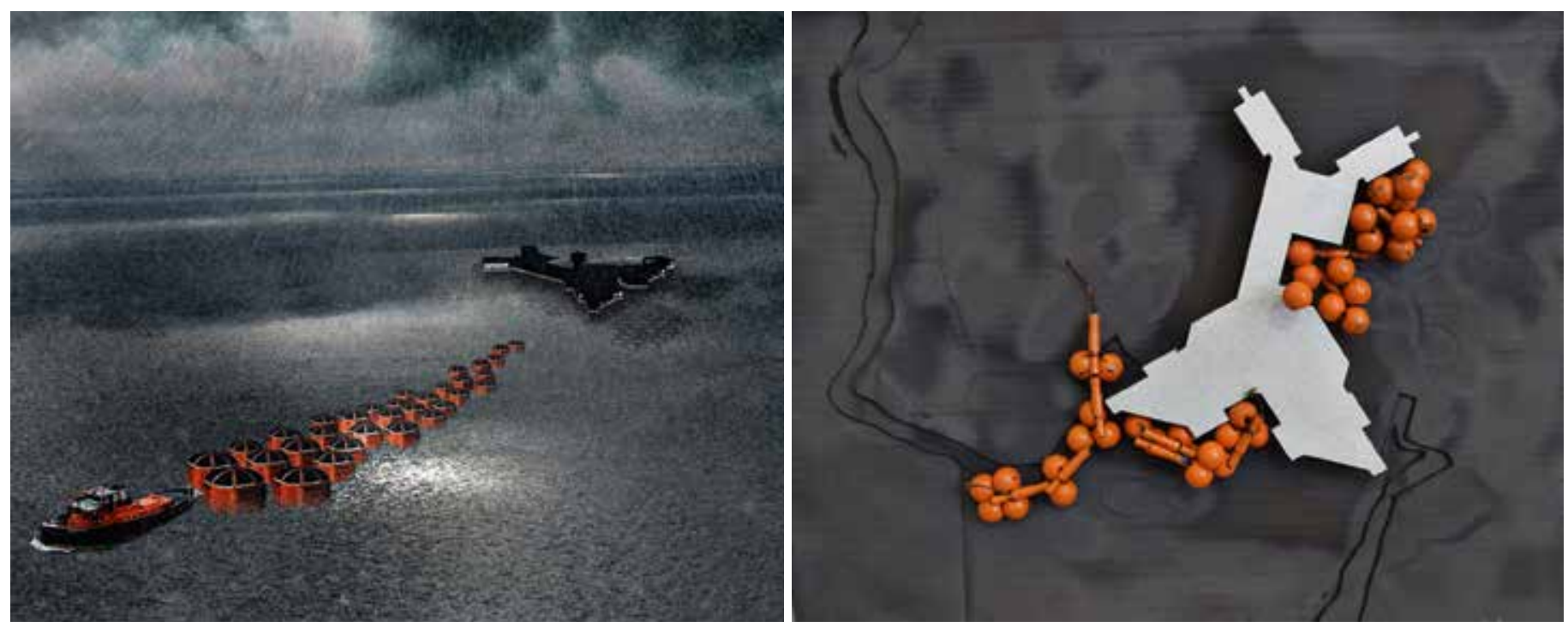

Figure 15. Mobility: final render image and early process model of LSU MArch student Ana Orosco. The resolution proposes reusing the facility for storage and infrastructure while creating a floating dock for a flotilla of research/living vessels. Inspired by the oil and gas offshore constructions, this future can pack up and move to a new location as needed.

These responses came from the students' work. As the studio finalized and the author prepared the presentation for the Grapple panel, the students' design projects and their closing observations dictated the aforementioned classification terms. It is the author's observation that these responses were heavily influenced by the studios' amphibian analysis and the field excursion experience. The constructed analysis of how amphibians negotiate both land and water and the experiential catalogue of how humans engage the coastal edges provided precedents (both successful and not) for the students to incorporate. The coastal occupations and the amphibians clearly presented mobility, augmentation, and elevation strategies of adaptation. As the students consistently documented their design research and process throughout the course, their constant analysis of what they were doing and why it was responsive to the issues, made it easy for the author to codify the responses.

The genesis of these responses were also instilled with the student's access and interaction with the original designers, researchers, maintenance staff, and leaders of the facility. These scientists, boat pilots, architects, engineers, and wetland specialists, etc. not only imparted valuable data and statistics, but in their presentations of current issues they face currently and their future thoughts, they collectively presented the need for a future to be developed. They did not articulate, in any way, specific building ideas, but they did speak to continued operations, adaptation, and resiliency, which directly influenced the methods of investigation the student had pursued. At a minimum, their appreciation of both physical structure and the institutional objective guided the overall studio's desire to find ways to persist. 
The presentation of these findings to the panel at the beginning of the first meeting has initiated the same effect that the aforementioned studio strategies did for the students. The convincing analyses and research coupled with the graphic resolutions that portray the future of the building and its world, propelled the discussion away from the problem-solving focus and towards a more imaginative and opportunistic potentiality. As so often, the discussions of the changes coastal environments face are despairing and seemingly hopeless, it inspires the author that in a conference room sitting above the rising tides, an organization looks to the future differently. There is a clear understanding that the values and challenges that the ocean offers (especially in ecotone sites) must be constantly investigated for and presented to human populations for if not, as humans generally occupy the land, the ocean and all its relevance to humankinds' survival can be forgotten or seem remote. The students, Grapple, LUMCON and "The SEA Is Coming" Integrative-Design studio hopefully can provoke a profound rethinking of current conventions about coastal change and occupancy, design, community, the environment, and where buildings can (and should) be.

\section{Notes}

1. "Percentage of Total Population Living in Coastal Areas," Socioeconomic Data and Applications Centre (SEDAC), NASA, accessed December 30, 2016, http://sedac.ciesin.columbia.edu/es/papers/Coastal_Zone_Pop_Method.pdf. 2. "Welcome," Louisiana State University Coastal Sustainability Studio (LUMCON), accessed November 15, 2016, https://lumcon.edu/.

3. "Concepts \& Principles," --, accessed November 30, 2013, http://css.Isu.edu/conceptprinciples/.

4. Joe Marlborough (LUMCON's Marine Superintendent), interview by Julie Olson, LSU MArch graduate student, October 21, 2016, "Personal Interview," written.

5. "LUMCON's History: 1979-2004," LUMCON, accessed 29 October 2016, https://lumcon. edu/information/history/.

6. Ibid.

7. Don O'Rourke (Director of firm O'Rourke, Gossen \& Associates), interviewed by Julie Olson, October 12, 2016, "Personal Interview," written.

8. "The Cajuns, Hurricane's, Floods and Fires in Louisiana History," David Roth, accessed November 9, 2016, http://www.thecajuns.com/lahurricanes.htm.

9. National Geographic, s.v. "delta," by Caryl-Sue, Jeannie Evers and Emdash, eds., accessed October 22, 2016, www.nationalgeographic.org/encyclopedia/delta.

10. O'Rourke, Gossen \& Associates, Louisiana Universities Marine Consortium Construction Documents, (Lafayette LA, USA: O’Rourke, Gossen \& Associates, October 8, 1982), complete set.

11. John Atkinson, "Soil Description and Classification," GeoTechniCAL Reference Package (London: City University, May 2000), accessed October 29, 2016, http://environment.uwe. ac.uk/geocal/SoilMech/classification/default.htm.

12. Ibid.

13. Dictionary.com, s.v. "waffle-slab," accessed November 8, 2016. http://www.dictionary. com/browse/waffle-slab.

14. O’Rourke, "Personal Interview."

15. Marlborough, "Personal Interview."

16. Julie Olson, "The Site Today," Pervious Passages, (Baton Rouge LA, USA: LSU MArch

Student Publication, 2017), 50. 
17. Craig McClain, Master Plan 2016-2020 (Cocodrie LA, USA: LUMCON Administration, 2016), https://lumcon.edu/wp-content/uploads/2016/10/5-year_Master_Plan_2016-2020.pdf. 18. "Amphibians," accessed January 8, 2016. http://www.aquaticcommunity.com/amphibians/. 19. John Hamilton, You Write It: Science Fiction, (Minneapolis MN, USA: ABDO Publishing, 2009), 8-9.

20. Brian M. Stableford, Historical Dictionary of Science Fiction, (Lanham MD, USA: Scarecrow Press, a division of Rowman \& Littlefield, 2004).

21. Wikipedia, s.v. "Worldbuilding," accessed January 8, 2016, https://en.wikipedia.org/wiki/ Worldbuilding.

22. "Student Performance Criteria," National Architecture Accrediting Board (NAAB) 2015 Conditions for Accreditation, pp. 17-18, accessed August 8, 2017, http://www.naab.org/wpcontent/uploads/01_Final-Approved-2014-NAAB-Conditions-for-Accreditation.pdf.

23. The meaning of grapple is as important as the acronym. Merriam Webster, s.v. "grapple," accessed August 20, 2017, https://www.merriam-webster.com/dictionary/grapple.

24. Alex Kolker, email meeting agenda, May 18, 2017.

\section{Acknowledgments}

"The SEA Is Coming" Integrative-Design Studio received funding to support the field excursion. The LSU CSS provided $\$ 2,000$, the LSU School of the Coast \& Environment provided $\$ 1,000$, and LUMCON provided free lodging and a small boat excursion.

\section{Credits}

Figures 1 and 4: photos by the Author.

Figures 2 and 3: diagrams constructed by Louisiana State University (LSU) MArch student Julie Olson.

Figure 5: model constructed by LSU BArch student Jacob Thevenot.

Figure 6: images by LSU MArch student Kim Breaux.

Figures 7 and 9: images by LSU BArch student Jacob Thevenot.

Figure 8: map image by LSU BArch student James Terrebonne.

Figure 10: drawing by LSU BArch student Jacob Thevenot and photo by MArch student Barry Holton.

Figure 11: drawing by James Terrebonne and photo by Jacob Thevenot, LSU BArch students. Figure 12: image composed by the Author.

Figure 13: images by LSU BArch student Jacob Thevenot.

Figure 14: images by LSU MArch student Kim Breaux.

Figure 15: images by LSU MArch student Ana Orosco.

Ursula Emery McClure, FAAR, AIA, LEED AP BD+C, holds a MArch from Columbia University and is the A. Hays Town Professor in the Louisiana State University School of Architecture. She is a founding partner of the firm "emerymcclure architecture," whose work has won numerous awards including recognitions by the 2006 and 2010 Venice Biennale. In 2008, the firm won the Gorham P. Stevens Rome Prize for their project "Terra Viscus: Hybrid Tectonic Precedent." E-mail: uemery@Isu.edu 